\title{
Popular Sovereignty After Brexit
}

\author{
Eoin Daly ${ }^{1}$ \\ ${ }^{1}$ School of Law, National University of Ireland, Galway, Ireland \\ Corresponding author: eoin.daly@nuigalway.ie
}

(Received 14 December 2020; accepted 07 April 2021)

\begin{abstract}
The Brexit referendum highlights the apparently anomalous role of the "people" in the constitutional order of the United Kingdom. Politically speaking, its verdict is acknowledged as unassailable and unaccountable, yet this "sovereign" status has no legal grounds. In turn, some commentators have argued that this discrepancy between "political" and "legal" understandings of popular sovereignty—or the failure to properly institutionalize popular sovereignty in a legal-constitutional form-represents a distinct site of constitutional crisis in its own right. However, I argue that such claims of constitutional anomaly, or of British exceptionalism in this regard, are misplaced. While the Brexit scenario seems to express the destabilizing and disruptive potential of a popular sovereign that exceeds or evades constitutional recognition, this is in no sense a peculiarity of the British constitutional order. By its nature, popular sovereignty is inexhaustible by constitutional recognition, and so it tends to retain such disruptive potential regardless of whatever constitutional form it is assigned. Thus, critics of the British constitutional status quo overestimate the capacity of constitutional law in general to regulate or domesticate the expression of popular sovereignty via referendums.
\end{abstract}

Keywords: Brexit; referendum; popular sovereignty; parliamentary sovereignty

\section{A. Introduction}

One of the most interesting questions arising from the Brexit vote is the status of the referendum itself, and more particularly, its relation to an emergent or putative principle of popular sovereignty. This question arises amidst an apparent paradox that, whereas the British people remain legally unrecognized as a constitutional agent and a "sovereign," their decision expressed in the referendum result is understood as unassailable or indeed, as unaccountable by the relevant actors. And unaccountability, in turn, is traditionally understood as a hallmark of sovereignty. What emerges then, is apparently the spectre of a popular verdict that is recognized as "sovereign" by constitutional and political convention, but that is unrecognized and therefore, unstructured and unregulated by constitutional law. Critically, many legal scholars have argued that this discrepancy between the political clout of the referendum on the one hand, and its lack of recognition in legal doctrine on the other, is itself partly constitutive of the current crisis - or at least represents a separate site of crisis in its own right. The absence of a legalconstitutional structure for popular sovereignty has been partly blamed for both allowing a destabilizing referendum to have been held, and for the uncertainty and disruption of its aftermath.

In this article I argue that such claims of constitutional anomaly or indeed, of British exceptionalism, are misplaced. On the one hand, I will argue that the Brexit referendum can be understood as expressing popular sovereignty in certain, historically meaningful senses, simply because of the acknowledged unaccountability of the people's verdict-notwithstanding the apparently

Eoin Daly Lecturer above the Bar, School of Law, National University of Ireland, Galway, Ireland. 
contradictory and competing doctrine of parliamentary sovereignty. On the other hand, I will argue that the under-institutionalized character of popular sovereignty in the British Constitution-with its apparently free-floating and elusive character-is in many ways quite unremarkable. Paradoxically, the people always retain a constitutional role that exceeds any specific constitutional recognition it may be assigned. And while there might well be certain advantages to greater institutionalization or recognition of popular sovereignty, the principle by its nature is inexhaustible by any mechanism of institutional recognition, meaning, in turn, that it retains a residual capacity for apparently arbitrary forms of disruption and destabilization. Indeed, in codified constitutional systems that specify conceptual and procedural frameworks for referendums, historical experience has shown that popular sovereignty, expressed through referendums, tends to retain the same disruptive, disorderly qualities that many commentators have attributed to the apparently more ad hoc framework used in the United Kingdom (UK). In particular, constitutional regulation of referendums generally struggles to stem the instrumental and ad hoc uses that have been criticized in the British context. Therefore, the crisis that the Brexit referendum caused should not be too readily attributed to questions of constitutional form, at least in this specific regard.

In the first section, I will consider the apparent anomalies of the British Constitution with regard to popular sovereignty and referendums, and particularly its apparent failure to recognize or formalize the constitutional role of the "people." In the second section, I will consider how an emergent principle of popular sovereignty, based in constitutional convention rather than law, relates to the legal doctrine of parliamentary sovereignty. In the third section, I will argue that the post-referendum critiques of the British constitutional order, and its under-provision for referendums, overestimate the capacity of constitutional law generally to regulate the expression of popular sovereignty via referendums. Thus, I will argue that the apparently disruptive, destabilizing effects of the Brexit referendum are not a peculiar feature of the British constitutional order, and in some respects simply reflect the elusive and inexhaustible qualities of popular sovereignty itself.

\section{B. Referendums and Sovereignty: British Anomalies?}

The Brexit referendum presents a number of apparent anomalies concerning both the constitutional status of the British people and the constitutional recognition of popular sovereignty more generally. On the surface, at least, the British Constitution seems exceptional or anomalous both in relation to referendums and to the concept of popular sovereignty in general.

Firstly, the British system appears distinctive because the "people" as such are not formally recognized as a constitutional agent. ${ }^{1}$ This is attributable, in part, to the absence of any consolidated codified constitution, the kind in which fundamental questions, such as popular sovereignty, tend to be addressed. Equally, it may be attributed not to the form, but to the content of the constitution, and more specifically, to the doctrine of parliamentary sovereignty itself. Because "sovereignty" is usually understood as being singular, exclusive, and indivisible, ostensibly the sovereignty of parliament admits of no competitor or superior. But because the superior moral authority of the people seems axiomatic, it would seem impossible to formalize a status for the people, which is somehow lesser or subordinate to that of a parliament that is supposed to represent it. This awkward matter is obfuscated through constitutional silence. ${ }^{2}$ Alternatively, in the Diceyan tradition, it might be said that popular sovereignty is recognized-but in a wholly separate non-juristic dimension, "political" rather than "legal"- thus avoiding any direct contradiction with parliamentary sovereignty. ${ }^{3}$

\footnotetext{
${ }^{1}$ See R (Miller) v. Secretary of State for Exiting the European Union [2017] UKSC 5, [2017] 1 All ER 158, [22] (appeal taken from EWHC) ("the judges know nothing of any "will of the people except as expressed in an Act of Parliament").

${ }^{2}$ Aileen McHarg, Navigating Without Maps: Constitutional Silence and the Management of the Brexit Crisis, 16 INT'L J. Const. L. 952 (2018).

${ }^{3}$ See James Kirby, A. V. Dicey and English Constitutionalism, Hist. Eur. IDEAS (2018) (analyzing Dicey's views on popular sovereignty).
} 
In a slightly more practical sense, the British Constitution is unusual because notwithstanding the relative novelty of referendums, it does not recognize a "constituent" power that is separate from the ordinary legislative power. Formally speaking, it makes no distinction between the power to create ordinary legislation and that of enacting fundamental laws. ${ }^{4}$ Richard Tuck traces this distinction to the 18th century in France and the United States and suggests that the undifferentiated sovereignty of the British parliament - applied to fundamental as well as ordinary laws-is a relic of premodern constitutionalism. ${ }^{5}$ Arguably, what distinguishes the British arrangement in concrete terms is not its failure to institutionalize "direct" democracy as such, but rather the absence of a specific, formal mechanism of any kind for the creation and revision of constitutional laws.

Secondly and relatedly, there is a divergence between the status of the referendum outcome in political practice and expectation, on the one hand, and its formal status in law, on the other hand. This problem came into dramatic focus in the Miller Supreme Court judgment concerning the claimed prerogative power of government to trigger exit from the European Union. ${ }^{6}$ Referendums are a relative novelty in British constitutional practice, and their status is contested and undefined. ${ }^{7}$ However, virtually all political actors recognized the referendum outcome had to be heeded, at least unless reversed in a subsequent referendum. ${ }^{8}$ Phillipson, in particular, argues there is now a constitutional convention stipulating that referendums are upheld. ${ }^{9}$ Tuck puts the case more strongly and suggests that while

technically they are merely consultative ... the idea that [referendums] could be disregarded seems to most people about as fanciful as the idea that the Queen could actually use the power . . . to veto a Parliamentary statute. ${ }^{10}$

\footnotetext{
${ }^{4}$ See Martin Loughlin, Constituent Power Subverted: From English Constitutional Argument to British Constitutional Practice, in The Paradox of Constitutionalism (Martin Loughlin \& Neil Walker eds., 2007).

${ }^{5}$ Richard Tuck, The Sleeping Sovereign: The Invention of Modern Democracy 249-83 (2016).

${ }^{6}$ Phillipson observes, “[T] he referendum was ... frequently described by lawyerly Remainers as 'only advisory' ... a dangerous gap had opened up between the popular perception of who was deciding the issue of withdrawal (the people, through the referendum) and the elite, 'insider', legal view: that the real decision remained one for the institutions of government: either Parliament or the Executive."). Gavin Phillipson, Brexit, Prerogative and the Courts: Why did Political Constitutionalists Support the Government Side in Miller?, 36 U. QueEnsLand L. J. 311, 323 (2017). Similarly, Ekins and Gee note: "A common refrain was that the referendum was advisory not merely as a matter of law but also as a matter of constitutional practice, such that Parliament remained as free as ever-politically as well as legally-to depart from the 'advice' of the voters." Richard Ekins \& Graham Gee, Miller, Constitutional Realism and the Politics of Brexit, in THE UK CONSTITUTION AFTER MilleR: BREXIT AND BEYOND (Mark Elliottt, Jack Williams, \& Alison Young eds., 2018).

${ }^{7} \mathrm{McHarg}$, supra note 2, at 956. "Referendums were subject to partial regulation by PPERA 2000, but this is mainly limited to conduct and finance rules ... Key issues, including the ... consequences of the vote, are left to be determined on a case-by-case basis." He argues that this uncertainty "reflects a common feature of the UK's highly flexible constitutional order, namely, the introduction of new constitutional practices in a gradual and piecemeal fashion, often for pragmatic reasons, without due attention to their broader constitutional significance."

${ }^{8}$ As Matthews puts it, "to describe referendums as merely advisory therefore neglects how their prevalence has fuelled public expectations regarding the way in which governments should respond to the popular will ... any attempt to overrule 'the people' is politically untenable." Felicity Matthews, Whose Mandate Is It Anyway? Brexit, the Constitution and the Contestation of Authority, 88 PoL. Q. 601, 607 (2017). Phillipson notes, the Government distributed a leaflet to every household stating: "This is your decision. The Government will implement what you decide." Phillipson, supra note 6, at 322.

${ }^{9}$ See Phillipson, supra note 6, at 322-23 ("[I]t is time to consider whether a convention should now be recognised to the effect that parliament and government will abide by the results of referendums."); Phillipson, supra note 6, at 322-23 (applying the Jennings Test to argue this constitutional convention is established "nearly all MPs plainly regarded themselves as bound to implement the result of the referendum, even where they passionately disagreed with it. They thus appeared to recognise a powerful norm binding on them."). See also McHarg, supra note 2, at 957 (noting that while "both the Conservative and Labour parties took the view that the referendum result was politically binding," this nonetheless "left the constitutional authority of the referendum essentially ambiguous . . . it is unclear whether [parties'] support for, or opposition to, the bill was in reality based on a principled decision about the democratic authority of the referendum (or its lack thereof), or simply upon a [political] calculation."); id. at 1327 (noting that the House of Lords Constitution committee declined to take a decisive view on this point in its 2010 report.) (citing Referendums in the United Kingdom 2009-2010 HL paper [99]).

${ }^{10}$ Richard Tuck, Brexit: A Prize in Reach for the Left, POL'Y EXCHANGE (July 17, 2017) https://policyexchange.org.uk/ pxevents/brexit-a-prize-in-reach-for-the-left/
} 
Claims of Scottish sovereignty or "constituent power," coexisting with Westminster's parliamentary sovereignty, might be understood in a similar sense-albeit being recognized by political, rather than strictly "constitutional" convention. ${ }^{11}$

In turn, if constitutional convention acknowledges the verdict as unassailable and the people as unaccountable in their decision, we can say that the people are constitutionally recognized, in some sense, as "sovereign," because while it is often conflated with sometimes mythological theories of constituent power, sovereignty is historically closely associated with the unaccountability of constituted power; ${ }^{12}$ the sovereign "must be immune from review, veto or punishment." 13 This "sovereignty" is potentially undermined by the discretion parliament enjoys, legally speaking, with respect to the choice to hold referendums. Discretionary recourse to the people is hardly consistent with its "sovereignty"; indeed, the people act reactively and even passively, and only "speaks" within a pre-constituted process. This might be understood in a similar sense to the discretion the UK government holds with regard to Scottish secession referendums. ${ }^{14}$ However, Bogdanor in particular has argued there is a further constitutional convention requiring referendums be held with respect to certain issues, and specifically, any transfer of powers from parliament, either supranationally or infranationally. ${ }^{15}$ Taken together, it might be argued these two conventions entail popular sovereignty in a meaningful sense, as the people are guaranteed a final say as to any reconfiguration of governmental powers. In a sense, these putative two conventions, taken together, do seem to amount to a nascent constitutional doctrine of popular sovereignty.

However, as we will see, it is the failure to enshrine a legal constitutional framework for referendums that has been the subject of recent criticisms. The political or conventional understanding of the authority of the referendum verdict-what has been referred to as "the de facto paramountcy of popular sovereignty" 16 -is not reflected in legal constitutional doctrine. ${ }^{17}$ The Supreme Court, in Miller, reaffirmed the orthodox view that the referendum result is purely advisory, partly because the sovereign parliament did not ascribe it binding status. ${ }^{18}$ Les Green, for

\footnotetext{
${ }^{11}$ See Stephen Tierney, Sovereignty and Crimea: How Referendum Democracy Complicates Constituent Power in Multinational Societies, 16 GERMAN L. J. 540 (2015) (referring to a Scottish "constituent power" that the UK government recognized as "irrepressible" in the context of the 2014 referendum); Zoran Oklopcic, Constitutional (Re)Vision: Sovereign Peoples, New Constituent Powers, and the Formation of Constitutional Orders in the Balkans 19 Constellations 81, 91 (2012) (explaining that no one would seriously dispute the constituent power of "the people of Scotland.").

${ }^{12} \mathrm{Kinch}$ Hoekstra, Athenian Democracy and Popular Tyranny, in POPUlar Sovereignty In Historical ConteXT (Richard Bourke \& Quentin Skinner eds., 2016). See also Matthew Landauer, The Idiōtēs and the Tyrant: Two Faces of Unaccountability in Democratic Athens, 42 Political Theory 139 (2014).

${ }^{13}$ HoEkstra, supra note 12 , at 17.

${ }^{14}$ In this light, Tierney argues that although the devolution settlement in Scotland reorients the UK constitution in a "plurinational" direction, "the structure of the settlement [also] embodies strong integrative tendencies that sustain the categorical distinction between host state national society, on the one hand, and substate national societies, on the other." Stephen Tierney, Giving with One Hand: Scottish Devolution within a Unitary State, 5 INT'L J. ConsT. L. 730, 731 (2007).

${ }^{15}$ Vernon Bogdanor, Brexit, the Constitution and the Alternatives, 27 KING's LAW J. 314 (2016)

${ }^{16}$ Matthews, supra note 8 , at 607.

${ }^{17} \mathrm{McHarg}$, supra note 2, at 957 (noting that the Brexit vote sparked a debate about what constitutional authority-if anyshould be accorded to the referendum." She also notes "an extraordinary outpouring of criticism-from politicians, journalists, lawyers, academics, and ordinary citizens - of the legitimacy of the referendum process, the quality of the referendum debate, and indeed of the compatibility of referendums with the UK's tradition of representative democracy.").

${ }^{18}$ This position was also reflected in the European Union Referendum Act 2015, which attributed no legal status to the result as such. European Union Referendum Act 2015, HL paper [99]. In Miller, the main debate on the constitutional status of the referendum focused on whether the vote affected the Government's claimed prerogative power to trigger withdrawal from the EU. R (Miller) v. Secretary of State for Exiting the European Union [2017] UKSC 5 [2017] 1 All ER 158, [22] (appeal taken from EWHC); As Phillipson puts the argument, "[ $\mathrm{t}$ ] he Government was giving effect to the result of a huge democratic exercise: the 2016 referendum." Phillipson, supra note 6, at 317. Forsyth argues that the referendum should have legal standing based on an understanding of the parliament having legislated to delegate the withdrawal decision to the people. See Christopher Forsyth, The High Court's Miller Judgment, Pol'y Exchange's Judicial Power Project (Nov. 8 2016), https://judicialpowerproject.org.uk/christopher-forsyth-the-high-courts-miller-judgment/. Mark Elliott puts the issue as follows: "Might . . . the fact that an exercise of popular sovereignty has taken place lessen the force exerted by parliamentary
} 
example, describes as "breathtaking" this idea that "any popular vote is of zero legal relevance until parliament expressly chooses otherwise."19

In summary, we might say that the British people are conventionally recognized as "sovereign" in that their decision is widely, if not unanimously, understood as binding, at least morally, on all state organs. ${ }^{20}$ But this understanding is completely out of kilter with formal constitutional doctrines. As Greene puts it, the courts have "ignored" the "emergence of the People as a constitutional agent." ${ }^{21}$ And this appears, to say the least, somewhat anomalous.

\section{Parliamentary and Popular Sovereignties}

I have argued that the British Constitution-in the broad sense that includes conventionsencompasses a version of popular sovereignty simply by recognizing the unaccountability of referendum verdicts. However, this is complicated by the fact that legal doctrine recognizes the parliament, rather than the people, as sovereign. This seems to underscore the anomalous and ad hoc nature of the U.K.'s constitutional position. And while some commentators have argued that the political reality of popular sovereignty should be matched by recognition in the legal and constitutional spheres, the question arises as to how any such principle would intersect or coexist with parliamentary sovereignty in its current form.

We are accustomed to thinking of sovereignty, by its nature, as being exclusive and indivisible, which ostensibly precludes, in principle, any coexistence of popular and parliamentary "sovereigns", or of state and sub-state sovereignties relating to say, Scotland. ${ }^{22}$ Yet the legal doctrine of parliamentary sovereignty has never precluded recognition of popular sovereignty, at least at some level, in the UK. Indeed, historically, the doctrines have coexisted in British political and constitutional thought. Rawlings, for example, refers to "an alternative and in some measures a complementary tradition of popular sovereignty" that "grew and persisted alongside parliamentary sovereignty." ${ }^{23}$ In the 17th century, many English republicans understood that Parliament represented the people's original authority. ${ }^{24}$ And similarly, some contemporary constitutional theorists have understood parliamentary sovereignty—as an institutional principle — as simply giving effect to popular sovereignty as a deeper political and moral principle. Poole, for example, rejects the idea that Parliament represents a fundamental political authority, and argues that whatever "constituent" power it enjoys derives fundamentally from the people, due to the electoral legitimacy of Parliament. ${ }^{25}$ For Murkens, similarly, "popular sovereignty was effectively absorbed

sovereignty-inspired interpretive presumptions that might otherwise lead to the conclusion that the prerogative remains excluded and unrevived?" Mark Elliott, Brexit, Sovereignty and the contemporary British constitution: Four perspectives, Pub. L. for Everyone (Dec. 16, 2016) https://publiclawforeveryone.com/2016/12/16/brexit-sovereignty-and-the-contemporarybritish-constitution-four-perspectives/. See also David R. Wingfield, The Brexit Case: Does the Constitution Have a Place for Democracy?, 35 U. QUEENSLAND L. J. 343 (2016).

${ }^{19}$ Les Green, Should Parliamentary Sovereignty Trump popular sovereignty?, LIMGREEN BLOG, (Nov. 3, 2016), https:// ljmgreen.com/2016/11/03/should-parliamentary-sovereignty-trump-popular-sovereignty/, (last visited Feb. 28, 2019).

${ }^{20}$ The government explicitly acknowledged "a democratic duty to give effect to the electorate's decision" by triggering Article 50. McHarg, supra note 2, at 956.

${ }^{21}$ Alan Greene, Parliamentary Sovereignty and the Locus of Constituent Power in the United Kingdom, 6 (2018), https://ssrn. com/abstract $=3247758$.

${ }^{22}$ See Tierney, supra note 14.

${ }^{23}$ Rawlings et AL., SOVEReignty and the Law: Domestic, European and InTERnational Perspectives 30 (2013).

${ }^{24}$ See Richard Bourke, Introduction, in POpUlar SOvEREIGNTY IN Historical CONTEXT (Richard Bourke \& Quentin Skinner eds., 2016).

${ }^{25}$ See Thomas Poole, Devotion to Legalism: On the Brexit Case, 80 MODERn L. REv. 685 (2017); Green, supra note 18 (“An influential line of [English constitutional] thought running from Hobbes, through Blackstone and Bentham, to Dicey and Jennings, equates popular sovereignty with Parliamentary sovereignty"). Greene, supra note 21, at 18 (discussing "that constituent power is possessed by the people instead appears to be axiomatic. Parliament becomes the locus for constituent power with its democratic credentials deployed to square the circle."). 
by and channelled through Parliament." ${ }^{26}$ Alternatively, Dicey portrays the people as equally possessing a "sovereignty," exercised through majoritarian elections, that coexists with parliamentary sovereignty, but similarly avoids any conflict between these sovereignties by assigning them to separate "legal" and "political" realms. ${ }^{27}$

Arguably, parliamentary and popular sovereignties are reconcilable conceptually as well as historically. This stems partly from the very different, and relatively modest, scope of each "sovereign" claim-a nuance which confounds the often totalizing and uncompromising connotations of the sovereignty concept. On the one hand, parliamentary "sovereignty" in some ways seems like an unfortunate misnomer, because it does not encompass any claim to constitutive or foundational authority-or what Loughlin and Tierney call sovereignty's "power-generative" dimension-and rather takes the form of an institutional-procedural principle concerning Parliament's legal jurisdiction. ${ }^{28}$ It provides an account of supreme legal power, rather than a theory as to the foundation or source of legitimacy. Arguably, it also sits uneasily with the older Hobbesian understanding of sovereignty as a supreme political jurisdiction, particularly because it does not encompass executive powers, and because of significant limits on the form in which its power is exercised. ${ }^{29}$ It might arguably be better termed parliamentary supremacy, because like what is often termed elsewhere as "judicial supremacy," it is expressed as a limited claim to supremacy in a defined legislative domain of constituted power. Parliamentary sovereignty is, as Green puts it, an "institutional device," not the foundational "moral ideal" that popular sovereignty represents. ${ }^{30}$

In turn, parliamentary sovereignty understood as a procedural-institutional principle is hardly inconsistent with some understanding of the people as an ultimate locus of power in politicalmoral terms. ${ }^{31}$ Loughlin and Tierney suggest that these limitations make parliamentary sovereignty an anomaly, one that blinds British lawyers to the deeper and constitutive scope of the sovereignty concept; ${ }^{32}$ but this also suggests that the principle leaves room for a constitutional doctrine of popular sovereignty that fills this gap.

Conversely, while parliamentary sovereignty does not preclude popular sovereignty, the reverse is arguably true as well. The idea of popular sovereignty has also been narrowed, in its scope and remit, in ways that equally eschew the totalizing or absolutist associations often associated with the concept-which, in particular, eschew any claim to supreme governmental power for the people as such. While Rousseau is often understood as adopting an uncompromising and absolutist doctrine of popular sovereignty, and as having adapted and democratized the Hobbesian concept, in fact, he pares back the remit of sovereignty significantly, in ways which make it plausible for a modern state. In particular, he insists that sovereignty is only exercised in a legislative domain. And he understands "legislation" in an idiosyncratically narrow sense, referring to something approximating fundamental law, rather than routine statute law. In a sense, this is simply an extension of Bodin's distinction between "sovereign" and "government"—one that, as Tuck points out, helps to adapt democracy to modern societies, by restricting the scope of popular sovereignty

\footnotetext{
${ }^{26}$ Jo Eric Khushal Murkens, Democracy as the legitimating condition in the UK Constitution, 38 LEGAL STUD. 42, 48 (2018).

${ }^{27}$ See Kirby, supra note 3.

${ }^{28}$ Martin Loughlin \& Stephen Tierney, The Shibboleth of Sovereignty, 81 Modern L. REv. 989 (2018).

${ }^{29}$ Pavlos Eleftheriadis, Law and Sovereignty, 29 LAW AND PHIL. 535, 551 (2010) ("the present Parliament is bound by at least one disability, the disability to make laws outside the existing procedural framework. This means that ... Parliament cannot be the holder of powers alone but is also the bearer of some disabilities as to law-making, in that there are some things that it cannot do.").

${ }^{30}$ See Green, supra note 18.

${ }^{31}$ Dicey defined the principle as follows: "[Parliament] has the right to make or unmake any law whatever; and, further, that no person or body is recognised by the law of England as having a right to override or set aside the legislation of Parliament." AV Dicey, Introduction to the Study of the Law of the Constitution 39-40 (8th ed., 1915)).

${ }^{32}$ Loughlin \& Tierney, supra note 28.
} 
to one-off constituent exercises. ${ }^{33}$ Since at least the 18th century and probably earlier, sovereignty has been conceptually distinguished from any crude idea of omnipotent rule. Popular sovereignty is then collapsed into, and limited to, the institutional recognition of the people's power of constitutional creation and amendment. On the one hand, this helps to resolve the apparent contradiction, highlighted by Maistre, whereby the people —in its abstract, undifferentiated sense- seem incapable of exercising sovereignty in the Hobbesian sense of a supreme political jurisdiction. On the other hand, and more to the point, this helps to show that popular sovereignty-much like parliamentary sovereignty in the UK-eschews political omnipotence as such, and limits its claim of supremacy to a specific, defined domain.

"Sovereignty," then, in both the popular and parliamentary contexts, simply refers to different, and not necessarily incompatible, claims of supremacy. This helps to reconcile the concept of sovereignty to the form of a complex multipolar state, where claims to supremacy necessarily operate in specific domains and so are not necessarily contradictory. Therefore, the apparent unassailability of the Brexit referendum is not, then, inconsistent with parliamentary sovereignty as such, at least when it is considered in an appropriately modest sense. Bogdanor argues that popular sovereignty not only now coexists with, but rather "supersedes" parliamentary sovereignty, because of the apparent constraint it imposes on Parliament to legislate against its own preferences. ${ }^{34}$ But this is a curious position, which seems to conflate parliamentary "sovereignty" with something like an unfettered, positive capacity to legislate without political, as distinct from legal, obstacle. Certainly, the referendum constrains the Parliament's capacity to legislate as it might please, politically speaking. But this is unremarkable. Parliamentary sovereignty surely never meant the absence of any constraint, in the fuller sense, on the capacity of parliament to pass laws of whatever kind. It is defined largely by the legally unfettered scope of parliamentary legislation, and the prohibition on judicial invalidation of statutes. There is no legal constraint on parliament legislating against the referendum verdict.

In this light, the apparent constraint the referendum imposes on parliament is no more of a dilution of its sovereignty than the constraints represented by public opinion, political expediency, or indeed the constraints of feasibility and realpolitik and so on. ${ }^{35}$ While it may be true that "the frequency of referendums ... has created a competing source of legitimacy and authority," 36 this does not undermine parliamentary sovereignty as understood in an appropriately modest and specific sense, unless "sovereignty" is conflated with more diffuse concepts of "government" and "power." It is telling that Douglas-Scott refers to parliamentary sovereignty as an "unlimited legislative power," because again, like Bogdanor's analysis, this arguably understands "sovereignty" as power, in the sense of power-to, as a positive freedom to effect legislative change against all obstacle. ${ }^{37}$ Indeed, running through much of the post-Brexit analysis, there has been a general conceptual confusion whereby "sovereignty" is implicitly conflated with governmental power tout court, rather than the more subtle sense-so helpfully elucidated by Tuck-of a differentiated,

\footnotetext{
${ }^{33}$ See Tuck, supra note 5.

${ }^{34}$ Vernon Bogdanor, Brexit, the Constitution and the Alternatives, 27 KING's L. J. 314 (2016). Similarly, Douglas-Scott argues: "Although there may be democratic arguments for referendums, their use might appear to undermine parliamentary sovereignty, if the popular vote goes against the preferences of the majority of MPs." Ros Taylor, Britain Voted Merely to Leave the EU. We Can't Assume Voters want a hard Brexit, The London School of Economics And Pol. Science Blog (Sept. 5 , 2016), https://blogs.lse.ac.uk/brexit/2016/09/05/britain-voted-merely-to-leave-the-eu-we-cant-assume-voters-want-a-hardbrexit/ (last visited Feb. 28, 2019).

${ }^{35}$ Michael Gordon, The UK's Sovereignty Situation: Brexit, Bewilderment and Beyond, 27 KING's L. J. 333, 337 (2016) ("legislative authority is limited by a range of crucial political, democratic, moral and practical considerations. Indeed, the entire justification for the doctrine of parliamentary sovereignty, and the legally unlimited legislative power which it allocates to the UK Parliament, is premised on the fact that this power is constitutionally limited, just not by law ... The referendum may be legally advisory, but it is no rejection of parliamentary sovereignty to recognise that its result is constitutionally binding.").

${ }^{36}$ See Matthews, supra note 8 , at 607.

${ }^{37}$ Sionaidh Douglas-Scott, Brexit, Article 50 and the Contested British Constitution, 79 Modern L. REv. 1019, 1026 (2016).
} 
specific power, a power to authorize, to license, to consent, to constitute or to resist, but not a power to govern as such. ${ }^{38}$

None of this, of course, is necessarily to say that parliamentary and popular sovereignties could be wholly reconciled or harmonized if, hypothetically, they were integrated within the same juristic order, in whatever form. Arguably, popular sovereignty is only reconcilable with parliamentary sovereignty in the current arrangement because it is recognized in constitutional convention rather than law. Any potential conflict between the doctrines is currently avoided by the fact the popular sovereignty is relegated to a separate "political" domain, as per the classical Diceyan analysis, thus preventing any conflict with the legal principle of parliamentary sovereignty. ${ }^{39}$ Yet, what is in contention in recent discourse, as considered in the next section, is the failure to recognize popular sovereignty in the legal-constitutional domain specifically, and the destabilizing effects that appear to stem from the absence of a legal-constitutional framework for popular sovereignty-both in terms of recognition and regulation. It is precisely this dualism - this relegation of popular sovereignty outside the legal domain-which McHarg and others argue has aggravated the current crisis. It might be argued whether it would be technically possible to constitutionally enshrine popular sovereignty understood as the unaccountability of the popular verdict in referendums, while at least preserving the negative dimension of parliamentary sovereignty, understood as the un-reviewability of statutes by courts. Arguably, it seems clear that were popular sovereignty hypothetically to be enshrined as a matter of constitutional law, this would be inconsistent with any power of Parliament to legislate against referendum results. But a more important question, which I consider in the remainder of the article, relates to how popular sovereignty itself can be successfully institutionalized and regulated in a legal-constitutional sense and whether this can stem the kinds of pathologies and dysfunctions that have been associated with the constitutional politics of Brexit.

\section{Regulating Referendum Politics: The Elusiveness of Popular Sovereignty}

So far, I have described an emergent understanding of the British Constitution as being somewhat anomalous or problematic in its relation to the "people." Particularly, it has been criticized for its failure to legally recognize the people or its sovereignty, and to meaningfully institutionalize and regulate popular sovereignty by providing a clear conceptual and procedural framework for constitutional referendums. Accordingly, it fails both to specify the authority and to regulate the use of constitutional referendums, considered as expressions of popular sovereignty. This failure to properly institutionalize popular sovereignty seems to have given it an uncertain, slightly freefloating, and lurking nature, with significant capacity to provoke and inflame political crisis. ${ }^{40}$ According to this narrative, popular sovereignty, occupying a kind of constitutional shadow world — politically but not legally recognized, and unregulated in its use-is potentially disruptive and chaotic because its interventions assume a highly irregular, undefined, undisciplined, and

\footnotetext{
${ }^{38}$ This is reflected, for example, in Martin Loughlin's description of the European Union Act 2011—which created a "referendum lock" for further integration as "a self-conscious abdication of Parliament's supposedly ultimate legal sovereignty in favour of popular political sovereignty." Martin Loughlin, The British Constitution: Thoughts on the Cause of the Present Discontents, 2 LONDON SCH. OF ECON. LEGAL DEP'T, 1 (2018). To the contrary, Tuck's analysis of sovereignty might suggest that it is the Act itself-designating the decision-maker-rather than the primary decision itself (via the referendum), which exercises "sovereignty." Tuck, supra note 5. In this light, Ekins argues that "departure from the EU is not strictly necessary to restore parliamentary sovereignty because it has never been legally qualified [by membership]." Ekins distinguishes between sovereignty understood as "Parliament's legally unconstrained authority to legislate (which should never have been in doubt)," and "Parliament's effective freedom to legislate on a wide range of questions which have otherwise been entrusted to the EU for decision." Accordingly, he argues that "[r] eferendums led by Parliament are an intelligible part of Westminster constitutional practice." Richard Ekins, Legislative Freedom in the United Kingdom, (2017) 133 LaW Q. REV. 582, 590-1 (2017).

${ }^{39}$ See Kirby, supra note 3.

${ }^{40}$ Matthews, pointing to a wider crisis of the British constitution preceding Brexit, refers to the emergence of "discretionary spaces" that have created "opportunities for competing claims to legitimacy to be advanced." Matthews, supra note 8 , at 608
} 
uncontained by constitutional law, driven instead by political expediency and realpolitik. Without a proper legal-constitutional framework, then, the nascent popular "sovereign" remains unpredictable and somewhat at large, even wild.

More specifically, this recent line of criticism identifies two particular ways in which the underinstitutionalization of popular sovereignty generates uncertainty and instability. It focuses, first, on the uncertain authority of the referendum and second, on its discretionary use-although this discretion may now be structured somewhat, as outlined by constitutional convention. ${ }^{41}$

$\mathrm{McHarg}$ in particular argues that these two constitutional gaps or silences are partly responsible for the current political crisis. As to the problem of discretion, she notes that the question of whether referendums are held on particular issues in the UK "is determined ad hoc and has been entirely driven by party political considerations rather than constitutional principle." ${ }^{\prime 2}$ In particular, this infamously allowed an open-ended question, with unclear consequences, to be put to the people. And as to the uncertain authority of the referendum, McHarg further argues that "the lack of clear understanding of the constitutional authority of the referendum [created] a potential conflict between parliamentary democracy and popular democracy, [because] it risked exposing the gulf between Parliament's claim to constitutional authority as a representative institution and the weakness of its democratic credentials in practice." ${ }^{3}$ Thus she argues these constitutional uncertainties "[contained] the seeds ... of a severe crisis of democratic legitimacy." ${ }^{44}$ Citing other constitutional "silences"- those pertaining to the territorial constitution and executive power as well as the referendum itself-McHarg argues: "[I]t is hard to avoid the conclusion that constitutional silence has also been responsible for the Brexit crisis." 45

While McHarg blames the crisis on the UK's constitutional adhocracy in unusually strong terms, this general idea is quite common in contemporary academic commentary, which focuses in particular on the absence of a framework of constitutional principle in relation to popular sovereignty and referendums. Mark Elliott, for example, argues that, in light of the increasingly common use of referendums, there is a "real need" to resolve "larger [constitutional] questions about the relationship between parliamentary and popular sovereignty." 46

Thus, it is widely argued that the lack of a clear conceptual framework for constitutional referendums, and particularly the uncertainty as to their authority and use, is both anomalous and potentially destabilizing. However, I will argue both that the apparent exceptionalism of the British situation is easily overstated, and that constitutional law has a relatively weak capacity to constrain and regulate referendum politics in the ways these critics appear to assume are desirable. I will argue that the apparently unstable, ad hoc, and elusive character of popular sovereignty in the UK is in fact quite unremarkable or even a generic feature of constitutional democracies that use referendums, regardless of the degree to which popular sovereignty is formally recognized in some legal-institutional form. Following the chaos of Brexit, we should not, indeed, overestimate the capacity of constitutional law to tame or contain the sometimes disruptive and destabilizing expressions of popular sovereignty in referendum form.

\footnotetext{
${ }^{41} \mathrm{McHarg}$ notes: "[T] $\mathrm{There}$ was no constitutional imperative to hold the referendum. Rather, the motivation was political: an attempt to resolve long-standing divisions in the Conservative party over the merits of EU membership, and to respond to the increasing electoral popularity of ... UKIP." Similarly "the first nationwide referendum, on EEC membership, in 1975-introduced, as in 2016, to resolve an internal dispute within the governing (Labour) party." McHarg, supra note 2, at 956.

${ }^{42} \mathrm{See} \mathrm{McHarg}$, supra note 2, at 659. Similarly, Tierney argues that referendums have been deployed based on party-political reasons rather than any constitutional principle Stephen Tierney, Direct Democracy in the United Kingdom: Reflections from the Scottish Independence Referendum, 4 PUB. L. 633 (2015).

${ }^{43}$ See McHarg, supra note 2, at 659.

${ }^{44} I d$.

${ }^{45} \mathrm{Id}$. at 967.

${ }^{46}$ Mark Elliott, Brexit, Sovereignty and the Contemporary British constitution: Four Perspectives, PUB. LAW FOR EVERYONE (Dec. 16, 2016), https://publiclawforeveryone.com/2016/12/16/brexit-sovereignty-and-the-contemporary-british-constitution-fourperspectives/.
} 


\section{The Elusiveness of Popular Sovereignty}

In comparative and conceptual terms, the apparent failure of the British Constitution to successfully regulate popular sovereignty in constitutional law is less remarkable and less significant than it might initially appear. On the one hand, I argued in the previous section that the people can meaningfully be recognized as sovereign merely because of the unaccountability of their verdict. And this sense of sovereignty can easily be institutionalized and indeed legally regulated in various familiar ways - for example, by legally recognizing the binding authority of referendum verdicts, or more importantly perhaps, by legally recognizing referendums as mandatory for some, or all, constitutional changes. At the very least, it may be possible to legally or constitutionally define the circumstances in which referendums are permitted or required, thus reducing the degree of political discretion as to their use. These are generally the kinds of remedies that critics of the UK's constitutional status quo have in mind. ${ }^{47}$ In particular, constitutional law or legislation might specify the permissible subject matter and form of referendums-including the abstract or concrete nature of the proposal-and the extent to which their use is required, or otherwise, for specific constitutional changes.

However, any such attempts at institutionalizing or regulating popular sovereignty are always partial and incomplete. Ultimately, these attempts may do little to stem potentially disruptive interventions made by - or on behalf of - the popular sovereign. By its nature and scope, popular sovereignty both eludes and exceeds institutionalization. I have argued that the people can be understood as "sovereign" in an historically meaningful way, simply by virtue of the limited supremacy or unaccountability that may be conferred on them in constitutional law. Yet, I have also argued that because this sovereignty-as-unaccountability operates within a certain, defined domain, it is essentially limited, paradoxically, by constitutional law. Thus, popular sovereignty is always institutionalized in a definite form, where such form itself operates as an obvious constraint. And any constitutional recognition of popular sovereignty contains an obvious paradox, because such recognition implicitly claims to limit the sovereign, while simultaneously recognizing its supremacy.

Another way of looking at this is to understand that the constituted form of popular sovereignty can never fully satisfy what I will call its supraconstitutional dimension-that is, the people's normative claim that lies outside the juristic domain and necessarily exceeds it. Accordingly, constitutional recognition can never exhaust the people's moral and political claim to reconstitute from outside, to impose a new form for its power. Thus, popular sovereignty can never be exhausted-or perhaps even domesticated-by legal-constitutional recognition; as Pereira puts it, "the sovereign moves uneasily inside and outside the Constitution," assuming a more or less institutionalized form depending on circumstance. ${ }^{48}$ Again, this highlights an important paradox: To institutionalize popular sovereignty is to assign its limits, yet simultaneously, to recognize popular sovereignty is necessarily to allow for extraordinary or revolutionary interventions that reject the institutional form assigned. Turner argues that

since not even the best practices of representation can ever fully capture the opinions and desires of a given constituency, that constituency always retains a wild power over its representatives - the power to say that the latter do not represent them, the power to deprive them of authority and stage their own. ${ }^{49}$

\footnotetext{
${ }^{47}$ See generally Tierney, supra note 42.

${ }^{48}$ See Thomaz Pereira, Constituting the Amendment Power: A Framework for Comparative Amendment Law, in THE Foundations and Traditions of Constitutional Amendment (Richard Albert, Xenophon Contiades, \& Alkmene Fotiadou eds., 2017).

${ }^{49}$ Jack Turner, The Constitution of Radical Democracy, 47 Polity 558, 559 (2015).
} 
But much the same observations apply to constitutional structures. The inevitable disparity between the principle of popular sovereignty on the one hand, and its contingent mechanism of institutional expression on the other, give it an inherently unstable or destabilizing character.

\section{Instrumentalizing Popular Sovereignty}

This peculiar feature of popular sovereignty_its free-floating, elusive, inexhaustible, and indeed slightly lurking quality - allows for two very different dynamics of disruption. One involves a kind of insurgency from below, an extra-legal intervention by the "people"-however constituted or defined-to reject its constitutionally assigned form and to reconstitute afresh, by whatever means. This often occurs when those who Frank calls the "underauthorized" seek to reconstitute the "people" itself on new terms, to "seize the mantle of authorization, changing the inherited rules of authorization in the process." ${ }^{\circ 0}$ However, a second and less obvious dynamic has greater resonance in the Brexit scenario. Rather than the people itself interloping from below, popular sovereignty may instead be instrumentalized from above. More specifically, the people's residual or reserve authority may be called upon or deployed, by political leaders or elites, in potentially novel or creative ways that are not necessarily recognized or envisaged in the existing constitutional form-and that are potentially used to bypass or overcome existing constitutional constraints. Thus, because popular sovereignty remains an inexhaustible principle irreducible to any contingent institutional expression, this not only allows the people to reject the formal limits imposed by such contingent arrangements, it also offers a symbolic resource to be instrumentalized by the constituted organs of government. The permanent gap between the claim of popular sovereignty and its mechanism gives a "wild" power not only to the people themselves, but also to their representatives or trustees. Going further again, we might say that all claims or expressions of popular sovereignty are mediated, orchestrated, or represented in some form-because of the impossibility of spontaneous or unmediated popular expression — such that all claims that are ostensibly claims of popular sovereignty are in fact claims made on its behalf. Indeed, this is the context and source of populism itself: The necessity of representation of the abstract "people", in the absence of any demanding or full-blown "democracy" in the sense of direct popular rule. ${ }^{51}$

In the Brexit scenario, the referendum might sometimes be depicted as insurgency or disruption from below, as a revolt by the people against elites. However, a much more obvious interpretation is that the people's "reserve" sovereignty is mobilized and deployed by, not against, elites. In this conceptualization, the people represents either an arbiter-whether of constitutional politics or of intra-partisan conflict-or, more obviously, a resource for elite instrumentalization, in particular where elites call on the people in order to "circumnavigate the veto capacity of other actors." ${ }^{2}$ In either case, the people do not spontaneously intervene, but are rather appealed to or instrumentalized; in particular, it may provide arbitration or legitimacy, whether in the symbolic or moral senses. Indeed, this provides some perspective on the view held by some political scientists that "most referendums are both controlled and pro-hegemonic. ${ }^{\text {"53 }}$

In turn, it is partly this possibility of political instrumentalization that is highlighted by McHarg, as being particularly problematic in-or even specific to- the UK's rather unusual constitutional arrangements. Constitutional "silence" as to popular sovereignty not only creates uncertainty about the authority of the referendum result, but also discretion as to its use. It is the discretionary recourse to referendum, amidst constitutional lacunae, that enables elite instrumentalization of popular sovereignty. On the surface, indeed this appears to generate troubling

\footnotetext{
${ }^{50}$ Jason Frank, Constituent Moments: Enacting the People in Post-revolutionary America 3 (2010).

${ }^{51}$ John McCormick, Democracy, Plutocracy and the Populist Cry of Pain, in Populism, Demagoguery, AND RHETORIC IN Historical PERSPECTIVE, (Giuseppe Ballacci \& Rob Goodman eds.) (forthcoming 2021).

${ }^{52}$ Matthew Flinders, Democratic Drift 234 (2010).

${ }^{53}$ See generally Mads Qvortrup, Are Referendums Controlled and Pro-Hegemonic?, 48 POL. STUD. 226 (2000).
} 
uncertainty or disorder, as the state may have recourse to referendums in circumstances that are not constitutionally regulated or defined. In summary, the UK's constitutional structure, and particularly its silence as to popular sovereignty, at least seems to aggravate the potential for disruptive intervention by, or more importantly, instrumentalization of popular sovereignty. It may be argued that these destabilizing tendencies could be remedied by greater constitutional regulation of the use of referendums, particularly by better defining their authority and use. Delaney goes as far as to argue that "had answers to these [constitutional] questions [about referendums] been made clear, Cameron would not have agreed to a referendum on Europe or the result may have been different, in light of complicated constitutional trade-offs that would have required resolution." ${ }^{24}$

Yet, in a wider perspective, these apparent peculiarities of the Brexit scenario are relatively unremarkable, simply because constitutional measures to regulate the use of referendums may do little to stem this disruptive or destabilizing dimension of popular sovereignty. Even where constitutionally enshrined, it retains its undomesticated supraconstitutional dimension. Accordingly, in constitutional systems where the principle is recognized and institutionalized in sometimes quite elaborate ways, this residual popular sovereignty has retained its potentially disruptive and destabilizing force. A good example is France. Since the revolution, French constitutional theorists - in contrast with the UK theorists-have developed rather specific, and sometimes quite intricate, constitutional doctrines concerning the respective roles of people, nation, and state. Moreover, and crucially, the function of such doctrines is largely to contain, tame, domesticate, or at least to focus popular power in recognized and regularized forms. And after a century in abeyance following the plebiscitarian practices of Napoleon III, referendums were revived as an instrument of constitutional amendment under the Fifth Republic. ${ }^{55}$

Yet, while the French framework provides both recognition and regulation of referendums, precisely the same dynamic of disruption, unpredictability, and more importantly, an easily instrumentalized popular sovereignty, have featured in the French experience of constitutional referendums. The inexhaustibility of popular sovereignty-its refusal to be contained within its assigned form-is evident in insurrectionary moments of insurgency and revolt, when the people appear to speak outside the approved channels. And this constituent force of the street is almost a leitmotif of French political culture. But more interestingly, for current purposes, this reserve or residual sovereignty is also evident in instances of elite orchestration or manipulation, where the people are called upon to provide arbitration or legitimation at moments of crisis. And crucially, this dynamic of referendums - the instrumentalization of popular sovereignty from above- has been a feature of the French experience notwithstanding a constitutional framework that ostensibly provides resolution both as to the authority and use of referendums.

In particular, the peculiar political dynamics of the Brexit referendum find important parallels in de Gaulle's use of referendums in France in the early Fifth Republic. ${ }^{56}$ While Article 89 of the Constitution allows for constitutional amendment either by referendum or through a parliamentary supermajority, de Gaulle twice instigated constitutional amendments using a separate provision for legislative referendums under Article 11, which unlike Article 89, allowed him to bypass parliament and to appeal directly to the people as a source of personal legitimation. ${ }^{57}$ The people,

\footnotetext{
${ }^{54}$ Erin F. Delaney, Brexit Optimism and British Constitutional Renewal, in CONSTITUTIONAL DemOCRACY IN CRISIS? 193 (Mark A. Graber et al. eds., 2018).

${ }^{55}$ See generally Michel Bouissou, Le pratique Referendaire en France, 28 REVUE INTERNATIONALE DE DROIT COMPARE 265 (1976).

${ }^{56}$ As Davies puts it, the Brexit referendum "was a gamble taken by Mr Cameron to neutralise a political threat that ultimately backfired spectacularly.” Bleddyn Davies, The EU Referendum: Who Were the British People?, 27 KING'S LAW J. 323, 325 (2016).

${ }^{57}$ The referendum was used by De Gaulle as a way of engaging his own political responsibility as President, similar to the manner in which he used parliamentary dissolution. Hugues Portelli, L'avenir du referendum en France, ETUDES 173, 180 (2000). See also Alibert-Fabre Véronique, La pensée constitutionnelle du général de Gaulle, 40 REVUE FRANÇAISE DE SCIENCE POLITIQUE 699 (1990); Duprat Jean-Pierre. Le référendum constitutionnel dans un système français dominé par une logique representative, 58 REVuE INTERNATIONALE DE DROIT COMPARE 553 (2006).
} 
in such circumstances, are potentially instrumentalized both as an extraordinary arbiter of crisis, and as a source of political capital or of legitimacy. ${ }^{58}$ While the use of Article 11 for constitutional amendment was constitutionally controversial and was not repeated after 1969, this feature of referendums remained true in France after the departure of de Gaulle and the demise of the Gaullist conception of the presidency and referendum, with recourse to referendums remaining highly discretionary and "political." ${ }^{9}$ Accordingly, in the remainder of the article I will consider how specific kinds of constitutional regulation of referendums, of the kind suggested by recent critiques, have limited capacity to stem the potentially disruptive effects of popular sovereignty expressed in this context.

\section{Discretionary Recourse to Referendums}

It is the very inexhaustibility of popular sovereignty as a supraconstitutional principle that makes it difficult for any constitutional recognition and regulation of referendums to reliably prevent any opportunistic, discretionary, or irregular recourse to the people, whether within or outside the established framework - and thus to stem the disruptive effects of the sort that have been associated with the Brexit referendum. A major criticism of the UK constitutional framework has been the absence of any measures curtailing political discretion as to the use of referendums. Certainly, there is unlimited discretion, legally speaking, both as to whether referendums-as distinct from mere parliamentary legislation-are used for a given constitutional reform, and to the content or subject matter that is appropriate for referendum. As already outlined, McHarg has argued that this discretion is, problematically, unguided by "constitutional principle", and driven by "political" considerations alone. Similarly, the House of Lords Constitution regretted "the ad hoc manner in which referendums have been used, often as a tactical device, by the government of the day." 60

Thus, it is implied that appropriate constitutional measures could, in principle, stem this problem. Leyland, for example, argues that "to prevent abuse by government clear rules need to be formulated to determine when constitutional referendums can be held." Yet even leaving aside possible instances of irregularity or illegitimacy as in the Gaullist example, the discretionary recourse that some British commentators have identified as problematic seems fairly intractable even under more typical constitutional arrangements where popular sovereignty is ostensibly regulated and proceduralized. Again, the French experience is instructive. The optional use of referendums for constitutional amendment in France under Article 89 leaves open a very similar dynamic of discretionary recourse to direct popular sovereignty. Thus, while the parliamentary mechanism has been the norm for constitutional amendments under the Fifth Republic, the referendum has occasionally been used at the discretion of state actors for high constitutional politics, usually in relation to matters of European integration, and particularly the Maastricht and Constitutional treaties in 1992 and $2005 .{ }^{61}$

Obviously, discretion remains a feature of referendums-politics in instances where constitutions, like France's, allow political choice as to the use of referendums within the constitutional

\footnotetext{
${ }^{58}$ Bouissou notes that de Gaulle used the referendum both to "short-circuit parliament" and to periodically shore up his "personal authority." Bouissue, supra note 55, at 266 (translated by author).

${ }^{59}$ Portelli notes that despite the end of the Gaullist use of the referendum, believed by some to be "plebiscitarian," it is still used occasionally by presidents "to gain political benefit from situations they believe as favoruable." Portelli, supra note 57, at 180 (translated by author). On the specificity of the French use of referendums in Europe and particularly its "presidentalist" orientation, see Hamon Francis, La crise du système référendaire, 43 DroITs 91 (2006) He identifies a "presidentalist" conception of direct democracy which is a "heritage of the bonapartist tradition that makes the emperor responsible before the people, to whom he always had the right to appeal." Id. (translated by author).

${ }^{60}$ Peter Leyland, Referendums, Popular Sovereignty and the Territorial Constitution, in SovereIGNTY AND THE LAW: Domestic, European and International Perspectives 141 (Richard Rawlings, Peter Leyland, \& Alison Young eds., 2013). See also House of Lords, Select Committee on the Constitution, (12th Report of Session 2009-10) HL 99 g 62 (UK).

${ }^{61}$ See generally Portelli, supra note 57.
} 
amendment process. However, it is also important to note that even in instances where the referendum is a mandatory instrument of constitutional amendment — for example, in Irelandaspects of possible opportunism and instrumentalization nonetheless remain. Despite the referendum being mandatory for constitutional amendments in Ireland, there is considerable political discretion as to the scope of constitutional amendment itself. The use of this discretion is partly informed by the political symbolism of the referendum device, with the rich source of political capital it potentially provides. In such circumstances, the referendum may represent a political instrument or resource in its own right, rather than simply a means to an end of effectuating a particular constitutional change. Constitutional amendments can be initiated, even contrived, for expressive, performative, or opportunistic ends, for the purpose of exercising recourse to the people. In Ireland itself, "constitutional" referendums have been initiated to decide all sorts of ostensibly non-constitutional issues, particularly social issues like abortion and divorce, children's rights, and even the legal status of the adoption authority. ${ }^{62}$ It may become an instrument for orchestrated collective self-expression, and thus a powerful political resource. Thus, the intractability of discretion in referendum politics stems from the permanent gap between the principle of popular sovereignty and its contingent institutional mechanisms.

Thus, even a comparatively rigid constitutional framework - which ostensibly leaves no political discretion as to the use of referendums in constitutional matters-does little to remove politics, in its raw sense, from the referendum process. A particularly good example of instrumentalization is the referendum on the twenty-seventh amendment to the Irish Constitution in 2004—removing jus soli citizenship — which many believed was initiated to capitalize on anti-immigrant sentiment for electoral purposes. ${ }^{63}$ In practice, indeed, the distinction between a referendum-which ostensibly pertains to a legislative question - and a plebiscite - used pejoratively as an instance of political instrumentalization or theatricality-is more tenuous than it might appear. ${ }^{64}$ Thus, whereas Leyland argues, "a fundamental problem is to avoid the arbitrary manipulation of a popular vote for political advantage," it is difficult to see how this can be avoided once provisions of any kind are made for referendums. ${ }^{65}$ As experience elsewhere shows, the idea of referendums as a purely neutral, juridically bound procedural mechanism unsullied by political opportunism or instrumentalization, is the product of wishful thinking by liberal legalists.

Indeed, the ease of instrumentalization of constitutional amendment referendums was reflected in the Italian referendum of 2017-conducted under a comparatively rigid constitution-where Prime Minister Renzi "deliberately turned a technical question of constitutional reform requiring formal approval, into a plebiscite for himself, and his Government, by promising to resign if he failed to achieve the desired outcome." ${ }^{66}$ Again, constitutional restrictions on the formal subject or content of referendums cannot necessarily control their underlying political use. Thus, where Douglas-Scott, for example, observes that referendums "have been used instrumentally by governments"-while making an argument as to the destabilizing indeterminacy of the British Constitution - seems to misconceive a kind of British exceptionalism, and overstates the capacity of constitutional law elsewhere to regulate the politics of referendum use. ${ }^{67}$ While Leyland, for example, refers to the "unprincipled" use of referendums in the British context, ${ }^{68}$ experience elsewhere suggests this criticism drastically overstates the capacity of codified constitutional systems to remove or constrain the "political" character of referendum use. McHarg, as I have described,

\footnotetext{
${ }^{62}$ Gavin Barrett, The Use of Referendums in Ireland: An Analysis, 23 J. LEGIS. STUD. 71 (2017).

${ }^{63}$ See Siobhán Mullally, Citizenship and Family Life in Ireland: Asking the Question 'Who Belongs'?, 25 LEGAL STUD. 578 (2005).

${ }^{64}$ Bouissou, supra note 57.

${ }^{65}$ Peter Leyland, Referendums, Constitutional Reform and the Perils of Popular Sovereignty, 3 Italian L. J. 121,121 (2017).

${ }^{66} \mathrm{Id}$. ("A common denominator then between the referendums conducted in the UK and Italy in 2016 was that in each case the Prime Minister was seeking voter endorsement to consolidate his own political standing.").

${ }^{67}$ See, e.g., Douglas-Scott, supra note 37.

${ }^{68}$ Leyland, supra note 60 , at 123 .
} 
argues that the U.K. is distinctive in a problematic way because the use of the referendum as a constitutional amendment device is highly discretionary, or "ad hoc," and indeed this has been a persistent theme in critical commentary on the U.K.'s legal architecture for referendums postBrexit. ${ }^{69}$ But again, this distinctiveness is easily overstated, because this discretionary character of constitutional referendums still applies in systems where they are more elaborately formalized and recognized as an instrument of popular sovereignty. This obviously applies where referendums are a discretionary feature of the constitutional amendment process, but it still applies even where they are a mandatory feature of the process, because both the initiation and scope of amendment itself remains highly discretionary and subject to various instances of instrumentalization.

Along with unregulated political discretion as to the triggering of referendums, there is a further complaint as to the lack of constitutional control on their content or subject matter, particularly whether or not they are confined to constitutional matters. It has been argued that the U.K. is unusual in having "no restrictions on matters that a referendum may be held on," 70 and this seems to accentuate the discretionary and therefore, potentially disruptive character of the referendum mechanism in the UK.

It has also been argued, of course, that it may be difficult to regulate or enforce what constitutes a legitimately "constitutional" subject. ${ }^{71}$ And the contrast with codified systems may easily be overdrawn, because of the flexibility - as seen in Ireland-as to the range of subject matters that may be enshrined as "constitutional." However, just as it is possible, in a technical sense to regulate the political choice of referendum, as distinct from legislation as a mechanism of constitutional reform, it is equally possible to regulate the subject matter that may be submitted to a constitutional amendment referendum. In a codified system, this can be achieved in particular, by limiting the scope of constitutional amendability itself, and in particular by specifying certain unamendable fundamentals. ${ }^{72}$ And while it is difficult to achieve this in the more flexible British system, there is nothing to prevent a statute regulating this matter, albeit without the same degree of entrenchment.

But deep regulation of this kind - as to the proper limits of direct democracy — cannot be done without raising questions of legitimacy and generating significant countervailing political costs, and in the more entrenched version at least necessitates judicial review not merely of parliamentary legislation but also of constitutional amendments, which is alien to British constitutional culture. Aside from questions of feasibility, we might, following Tuck's analysis, question whether such attempts to legally constrain political contingency are feasible or wise. Tierney, in this light, argues that "an attempt to set out definitively when a referendum must be used can be fraught with difficulties," citing the risks particularly of "juridify[ing] . . very political issue[s]" and that "overregulation can also result in perverse incentives."73

\section{The Indeterminacy of Referendum Proposals}

Perhaps even more significant than the open-ended subject matter, it has been argued that the UK's constitutional flexibility aggravated the referendum's disruptive effect because of a lack

\footnotetext{
${ }^{69} \mathrm{McHarg}$, supra note 2, at 958.

${ }^{70}$ See Jess Sargeant, Referendums in UK Democracy: How Should they Work in Practice?, The ConstitUTION UNIT BLOG (Nov. 28, 2017), https://constitution-unit.com/2017/11/28/referendums-in-uk-democracy-how-should-they-work-inpractice/ (last visited Mar. 29, 2021).

${ }^{71} \mathrm{See}$ House of LoRds, Select Committee on the Constitution, (12th Report of Session 2009-10) HL 99 (UK) (recognizing the difficulty of classifying "constitutional" issues and acknowledged the essentially "political" nature of the decision).

${ }^{72}$ See generally Yaniv RoznAi, UnCONSTitutional Constitutional AMENDMENTS: The Limits of AMENDMENT Powers (2017).

${ }^{73}$ Tierney, supra note 42, at 642 ("Each decision should in fact be left to Parliament on a [case-by-case] basis in recognition both of Westminster's legislative supremacy and of the essentially political nature of the decision at stake.”).
} 
of requirement of legislative specificity in referendum proposals. And the permissibility of such "pre-legislative" or "in principle" referendums seems to accentuate their already unpredictable and potentially disruptive quality.

More specifically, it has been argued that a great deal of the instability stemming from the Brexit referendum arose from the abstract, open-ended, or non-specific nature of the question posed. Additionally, it has been argued that the political crisis arose in large part because of this mismatch between the apparent moral authority of the referendum verdict, on the one hand, and the uncertainty as to its meaning on the other. Indeed, it is true that the UK's flexible constitutional framework permitted the holding of a referendum based on a relatively general question, and in the absence of defined legislative measures to which it would give binding effect, thus creating an apparently destabilizing disjuncture between the moral authority of its verdict and the undefined specifics of its implementation. McHarg concedes, on the one hand, that this "ambiguity over the constitutional authority of the referendum" may have "been beneficial in buying the government some extra time . . . to decide what form Brexit should take." However, she also argues, on the other hand, that it "prolonged and exacerbated the uncertainty of the situation" - and that, accordingly, a "clear obligation to implement the referendum result might have encouraged appropriate planning before the referendum, and discouraged the government from playing politics with the constitution with no clear idea of the potential consequences." ${ }^{\prime 4}$

Accordingly, it may be argued that an effective legal-constitutional framework should confine constitutional referendums to a ratification, or "post-legislative", role-as only confirming antecedently defined legislative proposals rather than being invoked as a relatively open-ended disruptive force. In this spirit, the Independent Commission on Referendums concluded: "Referendums should be held on proposals that are clear and immediately actionable." This meant, more specifically, that "referendums should be held post-legislatively: the relevant parliament or assembly should legislate in detail for the change, subject to approval by voters in a referendum." ${ }^{75}$ In turn, it has been claimed that such constitutional regulation would safeguard against the instability that arose in the aftermath of the Brexit vote. Trueblood says "using referendums to ratify rather than initiate constitutional change would go a long way to creating constitutional and political stability." ${ }^{\prime 6}$

However, on the one hand, I have already argued that the idea referendums could ever be confined to a purely ratificatory role misconceives them solely as instruments of legal-constitutional reform, rather than as inherently flexible political devices which offer significant political power to those who may invoke them. Because of this phenomenon, recourse to the people may be an end, not a means, even where in formal legal terms, the people only confirm an antecedently defined proposal. Politically speaking, the people may be called upon not simply to ratify, but as a source of moral and symbolic authority. On the other hand, constitutional systems that only provide for referendums as ratifying legislative proposals do not necessarily prevent the legislative proposal from itself being open-ended, vague, or contingent. Thus, in Ireland for example, where referendums may only ratify parliamentary bills proposing constitutional amendments, the Supreme Court ruled that nothing prevented the parliament from proposing constitutional amendments that were contingent on future events or that incorporated extraneous statutes. ${ }^{77}$

Therefore, the Diceyan idea that referendums should be used only as a veto device and thus as an exercise of "negative popular sovereignty" potentially overlooks how recourse to the people has a logic, purpose, and significance that are in large part separable from the subject matter of the

\footnotetext{
${ }^{74} \mathrm{McHarg}$, supra note 2, at 959.

${ }^{75}$ Const. Unit Sch. of Pub. Pol'y, Report of the Independent Commission on Referendums 203 (2018) https://www.ucl.ac.uk/ constitution-unit/sites/constitution-unit/files/182_-_independent_commission_on_referendums.pdf.

${ }^{76}$ Leah Trueblood, Referendums, Compromise and Ratification, UK CONSTITUTIONAL LAW BLOG (July 5, 2016), https:// ukconstitutionallaw.org/2016/07/05/leah-trueblood-referendums-compromise-and-ratification/ (last visited Feb. 28, 2019).

${ }^{77}$ Riordan v. An Taoiseach [2001] IESC 83 (HC); Morris v. Minister for the Environment [2001] 3 IR 326 (HC).
} 
vote itself, whether in symbolic or material senses. ${ }^{78}$ Indeed, it appears that whatever constitutional framework is in place, popular sovereignty, expressed in referendums, can never be rendered solely as a negative veto mechanism, or indeed as a neutral procedural instrument, precisely because the act or performance of the referendum provides political resources that are separate from and that exceed the constitutional goals that are ostensibly its subject. It offers a plastic resource for political organs that can be instrumentalized in diverse and unpredictable ways; often, but not solely for elite legitimation-whether by Renzi, De Gaulle and Cameron, in very different political circumstances and crucially, in diverse constitutional frameworks.

\section{E. Conclusion}

A persistent theme running through the Brexit commentary refers to an assumed "constitutional crisis", additional to and distinct from the political crisis. ${ }^{79}$ This supposed crisis is much wider than, but certainly encompasses, the UK's constitutional ambiguity as to the role of popular sovereignty and referendums. There is an obvious temptation for lawyers, academic or otherwise, to overstate the explanatory force of legal-constitutional structures and its influence in moments of political and social crisis. There is equally a recognizable impulse to assume that political contingency can be tamed using appropriate legal-constitutional forms. For example, Douglas-Scott argues that "considered constitutional principle" is the best "antidote" to the uncertainties generated by expressions of popular sovereignty. ${ }^{80}$ Underlying this, implicitly, there is a misplaced faith as to the capacity of constitutional law to safeguard the process of constitutional change against political contingency, or at least its capacity to do so without significant political costs. There is the perspective of depoliticization and juridification, which Honig describes as the perspective that seeks "to free modern subjects and their sets of arrangements [from] political conflict and instability." 81 One line of thought suggests that far from generating crisis, it is in fact the UK Constitution's relatively fluid and flexible character-its capacity to allow for political conflict and contingency to find acceptable conduits of expression - that help to secure democratic stability. Thus, Tuck argues that the U.K. Constitution has helped defuse extremism "because its political structures once again permit rather than constrain radical politics." 82 In effect, he argues that

\footnotetext{
${ }^{78}$ Leah Trueblood, The Merits and Meaning of a 'Second' Referendum, UK Constitutional Law Blog (Feb. 5, 2018) https://ukconstitutionallaw.org/2018/02/05/leah-trueblood-the-merits-and-meaning-of-a-second-referendum (last visited Feb. 28, 2019).

${ }^{79}$ Rebutting the narrative of crisis, Ekins and Gee argue, "the crisis narrative was the concoction of panicked elites; the constitution has to date enabled politics to work in established ways and through settled processes, and in so doing has provided sufficient political stability to absorb the shock of the referendum result." Ekins \& Gee, supra note 6, at 4 .

${ }^{80}$ Douglas-Scott also notes: "The British Constitution has become a contested and uncertain object, of sometimes ghostly and shifting form. As a result, we are thrown back onto politics, where the most powerful tend to dominate."). Douglas-Scott, supra note 37 , at 1026.

${ }^{81}$ Bonnie Honig, Political Theory and the Displacement of Politics 2 (1993).

${ }^{82}$ Tuck, supra note 10. Levinson and Balkin note: "Disagreement and conflict are natural features of politics. The goal of constitutions is to manage them within acceptable boundaries. When constitutional design functions properly-even if people strongly disagree with and threaten each other-there is no crisis. On the other hand, when the system of constitutional design breaks down, either because people abandon it or because it is leading them off of the proverbial cliff, disagreements and threats take on a special urgency that deserves the name of crisis.”). Sanford Levinson \& Jack M. Balkin, Constitutional Crises 157 U. PA. L. Rev. 707, 714 (2009). Interestingly in light of Tuck's analysis, they argue that "a central purpose of constitutions" is "to make politics possible" or "to channel and defuse difficulties and conflicts" and that "constitutional crises mark moments when constitutions threaten to fail at this task." Id. Accordingly, one "type" in their typology of constitutional crisis arises where "publicly articulated disagreements about the Constitution lead political actors to engage in extraordinary forms of protest beyond mere legal disagreements and political protests." Ibid. Therefore, whereas the use of referendums in the UK is seen as generating constitutional "crisis," it is plausible that the reverse might be true, because such a departure from traditional constitutional process may be a means of facilitating the expression of certain kinds of political demands that the existing system is ill equipped to handle. Fidelity to tradition, in the face of such political demands, might itself be a more likely source of "crisis."
} 
constitutional fluidity provides or allows for a kind of safety valve for political discontent, of which an ad hoc referendum might be one example. ${ }^{83}$ While I make no argument concerning the culpability or otherwise of the UK constitutional structure in general, I have argued, more specifically, against the view that the under-institutionalization of popular sovereignty should be understood as a distinct source of, or aggravating factor for, the political crisis surrounding Brexit. This is not to say that any greater institutionalization of popular sovereignty-or indeed, merely greater regulation of the referendum device-might not well have certain practical and political benefits. My argument, rather, is that we should not overestimate the capacity of constitutional form to effectively stem or regulate potentially destabilizing expressions of popular sovereignty.

\footnotetext{
${ }^{83}$ This contrasts with virtually all other academic commentators in contesting the assumption that the referendum has negative political consequences. By contrast, as Matthews puts it, the "bitter conduct of the campaign has ... exacerbated widespread dissatisfaction with the way in which Britain is governed.” Matthews, supra note 8, at 601.
}

Cite this article: Daly E (2022). Popular Sovereignty After Brexit. German Law Journal 23, 1-18. https://doi.org/10.1017/ glj.2022.3 